\title{
FACTORS AFFECTING EMBRYOGENESIS IN MICROSPORE CULTURES OF BROCCOLI (Brassica oleracea var. italica)

\author{
Badawi, M. A.*;
} \\ Marwa O. Arafeh* \\ * Department of Vegetable Crops , Faculty of Agric., Cairo Univ. , Egypt. \\ ** Department of Vegetable Crops , Faculty of Agric., Tanta Univ. , Egypt
}

\begin{abstract}
Microspore culture is a very important and useful tool in plant breeding for haploid production and has been developed for many years. Broccoli (Brassica oleracea var. italica) is an important vegetable crop. Conditions for reliable induction of embryogenesis from isolated microspores were studied in eight genotypes of broccoli (Hanin, Conde $F_{1}$, Baladi, Belstar $F_{1}$, Marathon $F_{1}$, Parthenon $F_{1}$, Naxos $F_{1}$ and Tiburom ). The optimum timing for microspore culture was confirmed to be during the mid to late uninucleate stage. The highest yield was 237.33 embryo per dish from genotype Parthenon $F_{1}$. Embryo yields were significantly increased in broccoli genotypes by the incubation at $32.5^{\circ} \mathrm{C}$ for 24 hours, than that incubated at $32.5{ }^{\circ} \mathrm{C}$ for 48 hours or $35.5{ }^{\circ} \mathrm{C}$ for 24 or 48 hours. The use of the $1 / 2 \mathrm{NLN}-13$ medium yielded greater number of embryos than the standard NLN-13 and B5 media. The magnitude of the response to the reduction of the concentration of major salts by half in the NLN medium varied with the different genotypes. Parthenon $F_{1}$ and Marathon $F_{1}$ presented a better response to the reduction of the concentration of major salts by half in NLN-13. Microspore culture density on embryo production was evaluated in selected genotypes. Microspore plating density was critical for efficient embryonic induction and development, with an optimal plating density of $4 \times 10^{4}$ microspore $/ \mathrm{ml}$. which obtained resulted in 237.33 embryo from Parthenon $F_{1}$ and 171.00 embryo from Marathon $F_{1}$. Activated charcoal $(0.2 \mathrm{ml})$ added to the liquid $\mathrm{NLN}-13$ medium, increased embryo yield significantly as compared to those cultures without activated charcoal.
\end{abstract}

\section{INTRODUCTION}

Brassica oleracea vegetables are an important and high diversified group of Brassica crops grown worldwide. Cauliflower ( $B$. oleracea var. botrytis) and broccoli ( $B$. oleracea var. italica) are the vegetable cole crops deserving the most breeding attention by seed companies. Microspore culture is an effective technology for : i) the production of homozygous parental lines (as an alternative to self-pollination) for the production of $F_{1}$ hybrids of modern cultivars of $B$. oleracea crops and ii) the increase in selection efficiency for desirable genetic recombinants. Successful microspore culture in different broccoli genotypes were described by Lichter (1989), Duijs et al., (1992) and Vicente and Dias (1996). A problem with the practical application of this technique is the very low embryo yield. Numerous factors are required for high levels of embryogenesis from Brassica microspores. These factors include culture media, growing conditions of donor plants, genotypes, microspore developmental stages, and the incubation of microspores at elevated temperature during the early stages of culture (Keller et al., 1987). Culture density is another factor that may influence microspore culture in Brassica. In this study, the effects of 
Badawi, M. A. et al.

genotype, culture medium, culture density, temperature treatment and activated charcoal on the efficiency of microspore embryogenesis in Broccoli (Brassica. oleracea var. italica) were examined.

\section{MATERIALS AND METHODS}

\section{Plant material:}

Eight commercial broccoli hybrids (Conde $F_{1}$, Belstar $F_{1}$ Marathon $F_{1}$, Parthenon $F_{1}$, Naxos $F_{1}$ ) and cultivars (Hanin, Baladi and Tiburom ) were used in the present study.

\section{Plant growth conditions:}

Plants were grown in a greenhouse using plastic pots of $16 \mathrm{~cm}$ diameter, fertilized with fertilizers as necessary and watered as required. Then they were verbalized for eight weeks, in an incubator room at $4 \pm 1^{\circ} \mathrm{C}$ with continuous light. After floral differentiation, and the start of generative development, all the plants were transferred to a growth chamber with a $16 \mathrm{~h}$ photoperiod and at temperature of $18^{\circ} \mathrm{C}$.

\section{Isolation of microspores:}

For both isolation and culture of the microspores, a sterilized filter, Nitsch and Nitsch medium (1967), as modified by Lichter (1981) and 13\% sucrose (NLN-13) was used. In the culture medium experiment, the NLN-13 medium was also used with concentration reduced by half (1/2 NLN- 13). Flower buds were harvested from young inflorescences. Up to 50 buds cauld be used for one isolation procedure. The microspore stages were observed cytologically at the mid to late uninucleate stage. The buds were surface sterilized. Then each sample of buds were transferred into $50 \mathrm{ml}$ beaker with $1.5 \mathrm{ml} \mathrm{NLN}-13$ medium and squeezed gently with the plunger, microspore suspension was obtained by filtration through $45 \mu \mathrm{m}$ nylon mesh screens. This suspension was centrifuged 3 times at $900 \mathrm{rpm}$ for $3 \mathrm{~min}$ and $20-30 \mathrm{ml}$ of $\mathrm{NLN}-13$ medium were added. ( $1 / 2 \mathrm{NLN}-13$ Medium, $\mathrm{B}_{5}$ Medium) then resuspended the total number of microspores with a haemocytometer to final density of $(3,4$ and 5$) .10^{4}$ microspores $/ \mathrm{ml}$. $10 \mathrm{ml}(9 \mathrm{ml}$ medium $+1 \mathrm{ml}$ medium with colchicine $0.01 \%$ ) were incubated at $32.5^{\circ} \mathrm{C}$ for $24 \mathrm{~h}$, then centrifuged for $3 \mathrm{~min}$ and10 $\mathrm{ml}$ medium were added and incubated at ( $32.5^{\circ} \mathrm{C}, 35.5^{\circ} \mathrm{C}$ for $24 \mathrm{~h}$ or $48 \mathrm{~h}$ ) in the dark in a growth chamber at $25^{\circ} \mathrm{C}$, after one week early pro-embryos were observed. After 2-3 weeks the dishes were transferred to a gyratory shaker at $60 \mathrm{rpm}$ at $24^{\circ} \mathrm{C}$ in the dark for one week, then embryos were transferred to $\mathrm{B}_{5}$ solid medium with $2 \%$ sucrose at $24^{\circ} \mathrm{C}$ for 4 weeks to allow the embryos to develop into plantlets. An addition of a $0.2 \mathrm{ml}$ per dish $(60 \mathrm{~mm}$. diameter) of activated charcoal to the culture dishes was performed according to Gland et al., (1988) and Dias (1999) procedures.

\section{Data analysis:}

Results were expressed as number of embryos per petri dish, In all experiments each treatment consisted of 8 dishes, a completely randomized design (CRD) was used with three replications, data were analyzed by Tukey's (HSD) test by Steel and Torrie (1960). 


\section{RESULTS AND DISCUSSION}

\section{Effect of genotypes on embryo induction and plantlets regeneration of broccoli:}

The $B$. oleracea genotype is considered to be a key factor for obtaining microspore-derived embryos. There was a significant variation in the response of the eight different broccoli genotypes to microspore culture (Table1). Parthenon $F_{1}$ (237.33 embryo/dish). Marathon $F_{1} \quad(171.00$ embryo/dish) were the highest responsive accessions studied Hanin, Conde $F_{1}$ and Baladi, were the lowest responsive microspore culture genotypes $\left(\left\{\neg, T \vee, \mid \Lambda, T \vee\right.\right.$ and $r, T V$ embryo/dish, respectivly) while Belstar $F_{1}$, Naxos $F_{1}$ and Tiburom showed no response. In total eight genotypes were tested, five produced embryos, but the yield of embryos was relatively low for most genotypes. B. oleracea is mostly self-incompatible and open-pollinated, and therefore genotypes are hetrogeneous to various degrees in the population. There is a plant to plant variation for microspore culture response within genotypes (Ferrie and Keller, 1995).

Table1. Effect of genotypes on embryo induction and plantlets regeneration of broccoli.

\begin{tabular}{|c|c|c|}
\hline Genotypes & No. Embryos / dish & No. Plantlets/ dish \\
\hline Conde F, & $1 \wedge, 7 \vee a$ & $\cdot, \mathrm{rra}$ \\
\hline Hanin & $\sum 7,7 \vee a$ & $1, \mathrm{rra}$ \\
\hline Bellstare $\mathrm{F}_{1}$ & $\cdot, \cdots \mathrm{a}$ & $\cdot, \cdots a$ \\
\hline Marathon $\mathrm{F}_{1}$ & $|v|, \cdots b$ & Or,TYb \\
\hline Parthenon $\mathrm{F}_{1}$ & $r M V, r T C$ & rr,rra \\
\hline Naxos F, & $\cdot, \cdots a$ & $\cdot, \cdots a$ \\
\hline Tiburom & $\cdot, \cdots a$ & $\cdot, \cdots a$ \\
\hline Baladi & $r, 7 v a$ & $\cdot, \cdots a$ \\
\hline
\end{tabular}

We compare means with a post-hoc test (Tukey's HSD test); Mean holding same letters are not significantly different on HSD at (0.05).

The present results confirmed the high embryogenic capacity of several broccoli genotypes: Parthenon $F_{\text {, }}$ and Marathon $F_{\text {, when compared }}$ to most of the $B$. oleracea genotypes, revealed a significant variability between genotype responses. Differences in responsiveness can be related to the different induction treatments used: $32.5^{\circ} \mathrm{C}$ for 24 hours by Takahata and Keller (1991) and the standard $30{ }^{\circ} \mathrm{C}$ for 48 hours (Duijs et al., 1992) Marathon $F_{1}$, was previously considered as unresponsive Pink (1999), but was highly responsive in the present study.

2- Effect of temperature treatment on embryo induction and Plantlets regeneration of broccoli.

Microspore embryogenesis in $B$. oleracea was routinely initiated by high temperature stress treatment of $32.5^{\circ} \mathrm{C}$ for 24 hours. For most of the $B$. oleracea varieties, this incubation temperature seems to be good. In the present experiment, out of the eight broccoli genotypes studied, two genotypes (Parthenon $F_{1}$, Marathon $F_{1}$ ) produced more embryos when incubated at $32.5^{\circ} \mathrm{C}$ for 24 hours $(237.33,171$ embryos/ dish ) than when

$$
0.79
$$


incubated at $30.5^{\circ} \mathrm{C}$ (Table 2). Embryo yields at $32.5^{\circ} \mathrm{C}$ for 24 hours was always significantly higher than at $32.5^{\circ} \mathrm{C}$ for 48 hours. Parthenon $F_{1}$ produced 109.67 embryo/dish when incubated at $35.5^{\circ} \mathrm{C}$ for 24 hour.

Table 2. Effect of temperature treatment on embryo induction and Plantlets regeneration of broccoli.

\begin{tabular}{|c|c|c|c|c|}
\hline Genotypes & Tem & ature $\mathrm{C}^{\circ}$ & No. Embryos / dish & No. Plantlets/ dish \\
\hline \multirow{4}{*}{ Conde $F_{1}$} & 32.5 & $24 \mathrm{~h}$ & $18.67 \mathrm{ab}$ & $0.33 \mathrm{a}$ \\
\hline & & $48 \mathrm{~h}$ & $0.0 \mathrm{a}$ & $0.0 \mathrm{a}$ \\
\hline & 35.5 & $24 \mathrm{~h}$ & $1.0 \mathrm{a}$ & $0.33 \mathrm{a}$ \\
\hline & & $48 \mathrm{~h}$ & $0.0 \mathrm{a}$ & $0.0 \mathrm{a}$ \\
\hline \multirow{4}{*}{ Hanin } & 32.5 & $24 \mathrm{~h}$ & $46.67 \mathrm{bc}$ & $1.33 \mathrm{a}$ \\
\hline & & $48 \mathrm{~h}$ & $1.0 \mathrm{a}$ & $0.0 \mathrm{a}$ \\
\hline & 35.5 & $24 \mathrm{~h}$ & $14.33 \mathrm{ab}$ & $0.33 a$ \\
\hline & & $48 \mathrm{~h}$ & $0.67 \mathrm{a}$ & $0.0 \mathrm{a}$ \\
\hline \multirow{4}{*}{ Bellstare $\mathbf{F}_{1}$} & 32.5 & $24 \mathrm{~h}$ & $0.0 \mathrm{a}$ & $0.0 \mathrm{a}$ \\
\hline & & $48 \mathrm{~h}$ & $0.33 \mathrm{a}$ & $0.0 \mathrm{a}$ \\
\hline & 35.5 & $24 \mathrm{~h}$ & $0.0 \mathrm{a}$ & $0.0 \mathrm{a}$ \\
\hline & & $48 \mathrm{~h}$ & $0.0 \mathrm{a}$ & $0.0 \mathrm{a}$ \\
\hline \multirow{4}{*}{ Marathon $\mathbf{F}_{1}$} & 32.5 & $24 \mathrm{~h}$ & $171 \mathrm{e}$ & $52.67 \mathrm{~d}$ \\
\hline & & $48 \mathrm{~h}$ & 3.00 & $0.0 \mathrm{a}$ \\
\hline & 35.5 & $24 \mathrm{~h}$ & $79.67 \mathrm{~cd}$ & $18.0 \mathrm{bc}$ \\
\hline & & $48 \mathrm{~h}$ & $9.33 \mathrm{ab}$ & $0.0 \mathrm{a}$ \\
\hline \multirow{4}{*}{ Parthenon $\mathbf{F}_{1}$} & 32.5 & $24 \mathrm{~h}$ & $237.33 \mathrm{f}$ & $23.33 \mathrm{c}$ \\
\hline & & $48 \mathrm{~h}$ & $18.0 \mathrm{ab}$ & $1.0 \mathrm{a}$ \\
\hline & 35.5 & $24 \mathrm{~h}$ & $109.67 \mathrm{~d}$ & $8.0 \mathrm{ab}$ \\
\hline & & $48 \mathrm{~h}$ & $2.33 \mathrm{a}$ & $0.0 \mathrm{a}$ \\
\hline \multirow{4}{*}{ Naxos $F_{1}$} & 32.5 & $24 \mathrm{~h}$ & $0.0 \mathrm{a}$ & $0.0 \mathrm{a}$ \\
\hline & & $48 \mathrm{~h}$ & $0.0 \mathrm{a}$ & $0.0 \mathrm{a}$ \\
\hline & 35.5 & $24 \mathrm{~h}$ & $0.0 \mathrm{a}$ & $0.0 \mathrm{a}$ \\
\hline & & $48 \mathrm{~h}$ & $0.0 \mathrm{a}$ & $0.0 \mathrm{a}$ \\
\hline \multirow{4}{*}{ Tiburom } & 32.5 & $24 \mathrm{~h}$ & $0.0 \mathrm{a}$ & $0.0 \mathrm{a}$ \\
\hline & & $48 \mathrm{~h}$ & $0.0 \mathrm{a}$ & $0.0 \mathrm{a}$ \\
\hline & 35.5 & $24 \mathrm{~h}$ & $2.33 \mathrm{a}$ & $0.33 a$ \\
\hline & & $48 \mathrm{~h}$ & $0.0 \mathrm{a}$ & $0.0 \mathrm{a}$ \\
\hline \multirow{4}{*}{ Baladi } & 32.5 & $24 \mathrm{~h}$ & $0.0 \mathrm{a}$ & $0.0 \mathrm{a}$ \\
\hline & & $48 \mathrm{~h}$ & $3.67 \mathrm{a}$ & $0.0 \mathrm{a}$ \\
\hline & 35.5 & $24 \mathrm{~h}$ & $0.0 \mathrm{a}$ & $0.0 \mathrm{a}$ \\
\hline & & $48 \mathrm{~h}$ & $0.0 \mathrm{a}$ & $0.0 \mathrm{a}$ \\
\hline
\end{tabular}

We compare means with a post-hoc test (Tukey's HSD test); Means holding same letters are not significantly different on HSD at (0.05).

Elevated culture temperature, as a pre-treatment for microspore embryogenesis is required for different Brassica species. The standard treatment of 48 hours at $30{ }^{\circ} \mathrm{C}$ used by Duijs et al., (1992) in six different cultivar groups of $B$. oleracea was shown to be less effective than the treatment of $32.5^{\circ} \mathrm{C}$ for 24 hours. This is in agreement with the results of Takahata and Keller (1991) and Halkjaer and Ringgaard (1997) which suggested $32.5^{\circ} \mathrm{C}$ for 24 hours as an incubation temperatures for broccoli microspores. Embryo yield was significantly reduced when the incubation temperature of $35.5^{\circ} \mathrm{C}$ was longer than 24 hours. Takahata and Keller (1991) also found that treatments at $35.5^{\circ} \mathrm{C}$ for 48 hours or longer produced less embryos than the optimal treatment of $32.5^{\circ} \mathrm{C}$ for 24 hours; this suggested 
that $B$. oleracea microspores are more sensitive to high temperatures than those of $B$. napus in order to enter into embryogenic development, where as the low temperature conditions; were considered as a nonembryogenic culture conditions; moreover it inhibits microspore embryogenesis in broccoli. Custer et al. (1994) in B. napus cv. Topas, reported a quite high number of embryos were produced at $25{ }^{\circ} \mathrm{C}$. This means that it is important to study the induction temperature for the different Brassica microspore culture systems.

3- Effect of genotype-media interaction on embryo induction and plantlets regeneration of broccoli.

Embryo yields were increased by reducing the concentration of major salts by half NLN-13 medium (Table 3). The reduction of major salts concentration in the NLN13 medium never have any detrimental effect on the embryo yield. Therefore, reducing concentration of major salts at half $\mathrm{NLN}-13$ medium seems to increase embryogenesis frequency in broccoli microspore culture. The magnitude of the response to the reduction of major salts in the medium varied with the different broccoli genotypes. The best results were obtained with the highly responsive genotypes 'Parthenon $F_{1}$ ', 'Marathon $F_{1}$ ' and 'Hanin' with significant increases in embryo yield (203.00, 171.00, 46.67 embryo/dish, respectively) (Table 2). Moderate differences were observed in the development of embryos into plantlets between the responsive genotypes. No differences were shown between the two other studied media (NLN-13, B5).

Table 3. Effect of genotype-media interaction on embryo induction and plantlets regeneration of broccoli.

\begin{tabular}{|c|c|c|c|}
\hline Genotypes & Medium & No. Embryos / dish & No. Plantlets/ dish \\
\hline \multirow{3}{*}{ Conde $F_{1}$} & $\mathrm{NLN}-13$ & $18.67 \mathrm{ab}$ & $0.33 \mathrm{a}$ \\
\hline & $1 / 2 \mathrm{NLN}-13$ & $1.00 \mathrm{a}$ & $0.33 \mathrm{a}$ \\
\hline & $\mathrm{B}_{5}$ & $0.33 \mathrm{a}$ & $0.00 \mathrm{a}$ \\
\hline \multirow{3}{*}{ Hanin } & $\mathrm{NLN}-13$ & $3.33 \mathrm{ab}$ & $0.67 \mathrm{a}$ \\
\hline & $1 / 2 \mathrm{NLN}-13$ & $46.67 \mathrm{~cd}$ & $1.33 \mathrm{a}$ \\
\hline & $\mathrm{B}_{5}$ & $0.00 \mathrm{a}$ & $0.00 \mathrm{a}$ \\
\hline \multirow{3}{*}{ Bellstare $F_{1}$} & NLN-13 & $0.33 \mathrm{a}$ & $0.00 \mathrm{a}$ \\
\hline & $1 / 2 \mathrm{NLN}-13$ & $0.00 \mathrm{a}$ & $0.00 \mathrm{a}$ \\
\hline & $\mathrm{B}_{5}$ & $0.00 \mathrm{a}$ & $0.00 \mathrm{a}$ \\
\hline \multirow{3}{*}{ Marathon $\mathrm{F}_{1}$} & $\mathrm{NLN}-13$ & $26.33 \mathrm{bc}$ & $14.00 \mathrm{ab}$ \\
\hline & $1 / 2 \mathrm{NLN}-13$ & $171.00 \mathrm{e}$ & $52.67 \mathrm{c}$ \\
\hline & $\mathrm{B}_{5}$ & $2.00 \mathrm{a}$ & $0.33 \mathrm{a}$ \\
\hline \multirow{3}{*}{ Parthenon $F_{1}$} & NLN-13 & $69.00 \mathrm{~d}$ & $29.67 \mathrm{bc}$ \\
\hline & $1 / 2 N L N-13$ & $203.00 \mathrm{f}$ & $23.33 \mathrm{ab}$ \\
\hline & $\mathrm{B}_{5}$ & $2.67 \mathrm{ab}$ & $0.00 \mathrm{a}$ \\
\hline \multirow{3}{*}{ Naxos $F_{1}$} & $\mathrm{NLN}-13$ & $0.00 \mathrm{a}$ & $0.00 \mathrm{a}$ \\
\hline & $1 / 2 \mathrm{NLN}-13$ & $0.00 \mathrm{a}$ & $0.00 \mathrm{a}$ \\
\hline & $\mathrm{B}_{5}$ & $1.67 \mathrm{a}$ & $0.67 \mathrm{a}$ \\
\hline \multirow{3}{*}{ Tiburom } & NLN-13 & $0.00 \mathrm{a}$ & $0.00 \mathrm{a}$ \\
\hline & $1 / 2 \mathrm{NLN}-13$ & $1.67 \mathrm{a}$ & $0.33 \mathrm{a}$ \\
\hline & $\mathrm{B}_{5}$ & $0.33 \mathrm{a}$ & $0.00 \mathrm{a}$ \\
\hline \multirow{3}{*}{ Baladi } & $\mathrm{NLN}-13$ & $3.67 \mathrm{ab}$ & $0.00 \mathrm{a}$ \\
\hline & $1 / 2 \mathrm{NLN}-13$ & $0.00 \mathrm{a}$ & $0.00 \mathrm{a}$ \\
\hline & $\mathrm{B}_{5}$ & $0.00 \mathrm{a}$ & $0.00 \mathrm{a}$ \\
\hline
\end{tabular}

We compare means with a post-hoc test (Tukey's HSD test); Means holding same letters are not significantly different on HSD at (0.05).

The nutritional requirements for induction and production of embryos vary widely from species to species. For microspore culture of $B$. oleracea, most researchers have used the standard NLN-13 culture media. In the

$$
0 . \mathrm{V}
$$


present study, $1 / 2 \mathrm{NLN}-13$ medium proved to be significantly better than NLN-13 medium for most of the broccoli genotypes studied. The explanation for the promotion of embryogenesis in all the genotypes tested, due to the reduction of major salts by half in the NLN-13 medium, needs to be clarified. Recently, Pink (1999) also reported a significant increase in embryo yield in an $F_{1}$ from a broccoli $\times$ cabbage cross by reducing the concentration of macronutrients by half in NLN medium. Sato et al., (1989), in B. campestris ssp. obtained similar results.

\section{4- Effect of genotype-microspores density on embryo induction and} plantlets regeneration of broccoli.

To investigate whether microspore plating density affected the efficiency of embryogenesis, isolated microspores transferred to NLN-13 medium at the densities of 3,4 and $5 \times 10^{4} \mathrm{per} / \mathrm{ml}$ and embryonic induction and development were investigated after 4 weeks of culture. Results obtained from cultures with different densities are shown in Table 4. The best embryo yield (237.33, 171.00 embryos / dish ) was achieved in cultures from Parthenon $F_{1}$, Marathon $F_{1}$, respectively with the density $4 \times 10^{4}$ microspores per $1 \mathrm{ml}$ of cultivation medium. Higher and lower densities ( 3 or $5 \times 10^{4}$ microspores per $1 \mathrm{ml}$ of cultivation medium, decreased the number of derived embryos per Petri dish. Culture density has significant effect on embryogenesis, and thus the capability of regeneration into whole plants (Huang et al., 1990 and Kott et al., 1988). In the present experiments, the best embryo yield was achieved with the density of $4 \times 10^{4}$ microspore/ $\mathrm{ml}$ of cultivation medium. Barro and Martin (1999) reported optimal density in Brassica carinata $10 \times 10^{4}-15 \times 10^{4}$ microspore $/ \mathrm{ml}$. Lichter (1982) and Zhou et al., (2002) reported the optimal density for Brassica napus $2 \times 10^{4}$ per $\mathrm{ml}$. Higher and lower density caused remarkable decrease in number of derived embryos per Petri dish and in the case of high density often protracted development and incomplete embryos. This issue could be the cause of nutrient competition among developing embryos and/or some toxic substances when older microspores are presented in the cultivation medium.

\section{5- Effect of activated charcoal on embryo induction and plantlets regeneration of broccoli.}

Embryo yields were significantly increased by the addition of $0.2 \mathrm{ml}$. of activated charcoal (AC) to the microspore culture media (Table 5). In no instance did the addition of $A C$ have any detrimental effect on embryo yield. Therefore $A C$ at a concentration of $2 \%$ seems to act as a promoter of embryogenesis in the microspore culture of different $B$. oleracea genotypes. The magnitude of the response to the addition of $A C$ varied with the different genotypes. The best results were obtained with Parthenon $F_{1}$ and Marathon $F_{1}$ with increases in embryo yield of 237.33, 171.00 embryo/dish, respectively which responded positively to the addition of AC. A qualitative improvement of the subsequent development of embryos in plants was also observed due to better embryos in presence of AC. These observations are in accordance with those of Gland et al., (1988) in B. napus. The response to the addition of $A C$ also seems to be dependent on the growth stage of microspores. 
Table 4. Effect of genotype-microspores density on embryo induction and plantlets regeneration of broccoli.

\begin{tabular}{|c|c|c|c|}
\hline Genotypes & Density & No. Embryos / dish & No. Plantlets/ dish \\
\hline \multirow{3}{*}{ Conde $\mathrm{F}_{1}$} & $3 \times 10^{4}$ & $0.00 \mathrm{a}$ & $0.00 \mathrm{a}$ \\
\hline & $4 \times 10^{4}$ & $18.67 \mathrm{a}$ & $0.33 a$ \\
\hline & $5 \times 10^{4}$ & $1.67 \mathrm{a}$ & $0.33 a$ \\
\hline \multirow{3}{*}{ Hanin } & $3 \times 10^{4}$ & $5.67 \mathrm{a}$ & $0.67 \mathrm{a}$ \\
\hline & $4 \times 10^{4}$ & $46.67 \mathrm{a}$ & $1.33 \mathrm{a}$ \\
\hline & $5 \times 10^{4}$ & $18.67 \mathrm{a}$ & $1.33 \mathrm{a}$ \\
\hline \multirow{3}{*}{ Bellstare $F_{1}$} & $3 \times 10^{4}$ & $0.00 \mathrm{a}$ & $0.00 \mathrm{a}$ \\
\hline & $4 \times 10^{4}$ & $0.33 a$ & $0.00 \mathrm{a}$ \\
\hline & $5 \times 10^{4}$ & $0.00 \mathrm{a}$ & $0.00 \mathrm{a}$ \\
\hline \multirow{3}{*}{ Marathon $\mathrm{F}_{1}$} & $3 \times 10^{4}$ & $35.00 \mathrm{a}$ & $10.33 \mathrm{ab}$ \\
\hline & $4 \times 10^{4}$ & $171.00 \mathrm{c}$ & $52.67 \mathrm{c}$ \\
\hline & $5 \times 10^{4}$ & $42.33 a$ & $9.33 \mathrm{ab}$ \\
\hline \multirow{3}{*}{ Parthenon $\mathrm{F}_{1}$} & $3 \times 10^{4}$ & $102.67 b$ & $8.33 a b$ \\
\hline & $4 \times 10^{4}$ & $237.33 d$ & $23.33 \mathrm{~b}$ \\
\hline & $5 \times 10^{4}$ & $124.33 b c$ & $10.67 \mathrm{ab}$ \\
\hline \multirow{3}{*}{ Naxos $F_{1}$} & $3 \times 10^{4}$ & $0.00 \mathrm{a}$ & $0.00 \mathrm{a}$ \\
\hline & $4 \times 10^{4}$ & $0.00 \mathrm{a}$ & $0.00 \mathrm{a}$ \\
\hline & $5 \times 10^{4}$ & $0.00 \mathrm{a}$ & $0.00 \mathrm{a}$ \\
\hline \multirow{3}{*}{ Tiburom } & $3 \times 10^{4}$ & $0.00 \mathrm{a}$ & $0.00 \mathrm{a}$ \\
\hline & $4 \times 10^{4}$ & $0.00 \mathrm{a}$ & $0.00 \mathrm{a}$ \\
\hline & $5 \times 10^{4}$ & $0.00 \mathrm{a}$ & $0.00 \mathrm{a}$ \\
\hline \multirow{3}{*}{ Baladi } & $3 \times 10^{4}$ & $0.00 \mathrm{a}$ & $0.00 \mathrm{a}$ \\
\hline & $4 \times 10^{4}$ & $3.67 \mathrm{a}$ & $0.67 \mathrm{a}$ \\
\hline & $5 \times 10^{4}$ & $1.67 \mathrm{a}$ & $0.33 a$ \\
\hline
\end{tabular}

We compare means with a post-hoc test (Tukey's HSD test); Means holding same letters are not significantly different on HSD at (0.05).

Addition of $A C$ has promoted embryogenesis in microspore culture of different $B$. oleracea, The explanation for the promotion of embryogenesis by $A C$ is not yet well clarified. AC possesses strong adsorptive properties and is usually used in chemistry to absorb both gases and dissolved solids. In different, Brassicaceae species, Lichter (1989) pointed out that addition of AC in an isolated microspore culture might remove toxic substances from the media. Gland et al., (1988) suggested also that AC acts by removing toxic substances released by non-reactive microspores thus allowing a larger number of embryogenic cells to develop. This explanation was also given by Kott et al., (1988), AC is capable of trapping gases and so may inactivate ethylene, or other gases, released from cultured tissues (Johansson et al., 1982). Dias and Martins (1998) observed that the inclusion of the ethylene antagonist silver nitrate in the medium increased embryo yields significantly in different morphotypes of $B$. oleracea as kales, kailan, cauliflowers, cabbages, tronchudas and broccolis. AC could absorb some phenols commonly produced by wounded tissues (Fridborg et al., 1978 and Weatherhead et al., 1979). However in Brassica microspore cultures, only low levels of phenolic compounds are expected in the microspore suspension since microspore cultures are almost devoid of somatic cell fragments. Although the release of some phenolic compounds of somatic cell fragments to the media can be a reality.

$$
0 . v T
$$


Badawi, M. A. et al.

Table 5. Effect of activated charcoal on embryo induction and plantlets regeneration of broccoli.

\begin{tabular}{|c|c|c|c|}
\hline Genotypes & $\begin{array}{c}\text { Activated charcoal } \\
0.2 \mathrm{ml}\end{array}$ & No. Embryos / dish & No. Plantlets/ dish \\
\hline \multirow{2}{*}{ Conde $F_{1}$} & Without AC & $10.00 \mathrm{a}$ & $0.67 \mathrm{a}$ \\
\hline & With AC & $18.67 \mathrm{a}$ & $0.33 \mathrm{a}$ \\
\hline \multirow{2}{*}{ Hanin } & Without AC & $28.67 \mathrm{a}$ & $1.00 \mathrm{a}$ \\
\hline & With AC & $46.67 \mathrm{a}$ & $1.33 \mathrm{a}$ \\
\hline \multirow{2}{*}{ Bellstare $F_{1}$} & Without AC & $0.00 \mathrm{a}$ & $0.00 \mathrm{a}$ \\
\hline & With AC & $0.33 \mathrm{a}$ & $0.00 \mathrm{a}$ \\
\hline \multirow{2}{*}{ Marathon $\mathrm{F}_{1}$} & Without AC & $108.33 \mathrm{~b}$ & $26.00 \mathrm{~b}$ \\
\hline & With AC & $171.00 \mathrm{c}$ & $52.67 \mathrm{c}$ \\
\hline \multirow{2}{*}{ Parthenon $\mathrm{F}_{1}$} & Without AC & $131.67 \mathrm{bc}$ & $9.67 \mathrm{ab}$ \\
\hline & With AC & $237.33 \mathrm{~d}$ & $23.33 \mathrm{~b}$ \\
\hline \multirow{2}{*}{ Naxos $F_{1}$} & Without AC & $0.00 \mathrm{a}$ & $0.00 \mathrm{a}$ \\
\hline & With AC & $0.00 \mathrm{a}$ & $0.00 \mathrm{a}$ \\
\hline \multirow{2}{*}{ Tiburom } & Without AC & $0.00 \mathrm{a}$ & $0.00 \mathrm{a}$ \\
\hline & With AC & $0.00 \mathrm{a}$ & $0.00 \mathrm{a}$ \\
\hline \multirow{2}{*}{ Baladi } & Without AC & $2.67 \mathrm{a}$ & $2.00 \mathrm{a}$ \\
\hline & With AC & $3.67 \mathrm{a}$ & $0.67 \mathrm{a}$ \\
\hline
\end{tabular}

In summary, our successtul generation of embryos and plants trom isolated broccoli microspores is mainly attributed to five key factors: (1) genotypes, (2) culture in 1/2 NLNS-13 medium supplemented with sucrose $130 \mathrm{~g} / \mathrm{l}$ as carbon source, (3) an optimization of microspore plating density at $4 \times 10^{4} \mathrm{microspore} / \mathrm{ml}$, (4) high temperature stress treatment of $32.5^{\circ} \mathrm{C}$ for 24 hours and (5) activated charcoal at a concentration of $2 \%$ seems to act as a promoter of embryogenesis. This information provides the basic framework for further improvements, and for future large-scale generation of embryos and plants from isolated microspores of broccoli. This microspore culture system, when optimized, may be used for genetic transformation, mutant selection for dominant and recessive traits, molecular studies on embryogenesis in addition to homozygous doubled haploid plants.

\section{REFERENCES}

Barro, F. and A. Martin (1999). Response of different genotypes of Brassica carinata to microspore culture . Plant Breed., 118:79-81.

Custers, J.B.M; J.H.G. Cordewener; Y. No"llen; H.J.M Dons and M.M. Van Lookeren Campagne (1994). Temperature controls both gametophytic and sporophytic development in microspore cultures of Brassica napus. Plant Cell Rep., 13:267-271.

Dias, J.S. and M.G. Martins (1998). Effect of silver nitrate on anther culture embryo production of different Brassica oleracea morph types. SECH, Actas de Horticulture, 22: 189-197.

Dias, J.C.S. (1999). Effect of activated charcoal on Brassica oleracea microspore culture embryogenesis. Euphytica, 108:65-69.

Duijs, J.G., R.E. Voorrips; D.L. Visser and J.B.M. Custers (1992). Microspore culture is successful in most crop types of Brassica oleracea L. Euphytica, 60: 45-55. 
Ferrie A.M.R. and W.A. Keller (1995). Microspore culture for haploid plant production. In: Gamborg, O.L., G.G. Phillips (eds.): Plant Cell, Tissue and Organ Culture: Fundamental methods. Springer, Berlin, pp. 155164.

Fridborg, G., M. Pedersen; M. Landstrom and T. Erickson (1978). The effect of activated charcoal on tissue cultures: absorption of metabolites inhibiting morphogenesis. Physiol. Plant, 43: 104-106.

Gland, A., R. Lichter and H.G. Schweiger (1988). Genetic and exogenous factors affecting embryogenesis in isolated microspore cultures of Brassica napus L. J. Plant Physiol., 132: 613-617.

Halkjaer, M. and S. Ringgaard (1997). Microspore Culture in B. oleracea L. COST-824 Gametic Embryogenesis Workshop, Book of Abstracts. Sjusjoen, Norway. p. 32.

Huang, B., S. Brid; R. Kemble; D. Simmonds; W. Keller and B. Miki (1990). Effects of culture density, conditioned medium and feeder cultures on microspore embryogenesis in Brassica napus L. cv. Topas. Plant Cell Rep., 8:594-597.

Johansson, L., B. Anderson and T. Eriksson (1982). Improvement of anther culture: activated charcoal bound in agar medium in combination with liquid medium and elevated $\mathrm{CO}_{2}$ concentration. Physiol. Plant, 54: 2430.

Keller, W.A., P.G. Arnison and B.J. Cardy (1987). Haploids from gametophytic cells-recent developments and future prospects. $p$. 223241. In: C .E. Green et al. (Eds). Proc. $6^{\text {th }}$ Int. Congr. Plant Tiss. Cell Cult. Alan R . Liss, Inc., New York.

Kott, L.S., L. Polsoni; B. Ellis and W.D. Beversdorf (1988). Autotoxicity in isolated microspore culture of Brassica napus. Can. J. Bot., 66: 16651670.

Lichter, R. (1981). Anther culture of Brassica napus in a liquid culture media. Z. Pflanzenphysiol, 103: 229-237(Abs.).

Lichter, R. (1982). Induction of haploid plants from isolated pollen of Brassica napus. Z. Pflanzenphysiol, 105: 427-434 (Abs.).

Lichter, R. (1989). Efficient yield of embryoids by culture of isolated microspores of different Brassicaceae species. Plant Breeding, 103: 119-123.

Nitsch, C. and J.P. Nitsch (1967). The induction of flowering in vitro in stem segments of Plumbago indica L. I. The production of vegetative buds. Plant, 72: 355-370 (Abs.).

Pink, D., (1999). Application of Doubled Haploid Technology and DNA Markers in Breeding for Club root Resistance in Brassica oleracea. COST-824 Gametic Embryogenesis Workshop, Book of Abstracts. Krakow, Poland, pp. 5-7.

Sato, T., T. Nishio and M. Hirai (1989). Plant regeneration from isolated microspore cultures of Chinese cabbage (Brassica campestris ssp. pekinensis). Plant Cell Rep., $8:$ 486-488.

Steel, R.G. and J.H. Torrie (1960). Principals and procedures and statistics A biometrical approach. McGraw-Hill Book Co., NewYork. 


\section{Badawi, M. A. et al.}

Takahata, Y. and W.A. Keller (1991). High frequency embryogenesis and plant regeneration in isolated microspore culture of Brassica oleracea L. Plant Sci., 74: 235-242.

Vicente, J.G. and J.S. Dias (1996). Production of embryos from microspore cultures of portuguese tronchuda cabbage landraces. Acta Horticulture, 407: 219-226.

Weatherhead, M.A.; J. Burdon and G.G. Henshaw (1979). Effects of activated charcoal as an additive to plant tissue culture media. $Z$. Pflanzenphysiol, 94: 399-406(abs.).

Zhou, W.J.; G.X. Tang and P. Hagberg (2002). Efficient production of doubled haploid plants by immediate colchicine treatment of isolated microspores in winter Brassica napus. Plant Growth Regulation, 37: 185- 192.

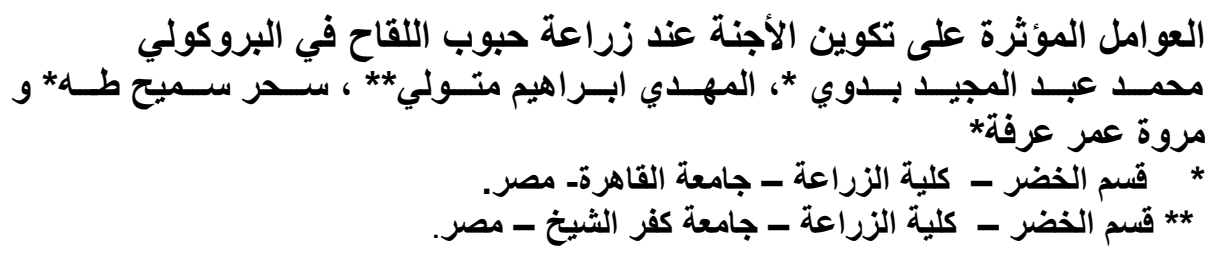

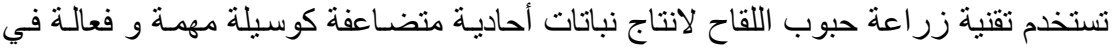

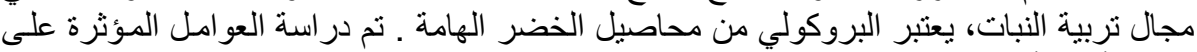

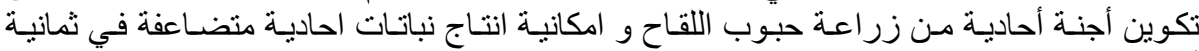
(Hanin, Conde F 1 , Baladi , Belstar F ( Parthenon $F_{1}$, Naxos $F_{1}$ and Tiburom

أفضل مرحلة لاستخلاص حبوب اللقاح كانت في مرحلة حبة اللقاح وحيدة النواة ـ أفضل الفيل

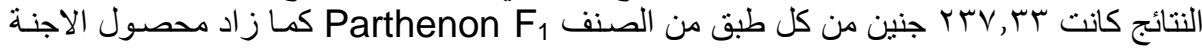

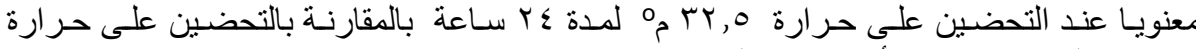

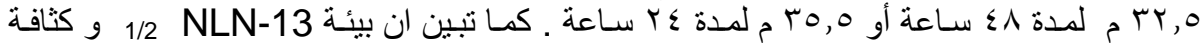

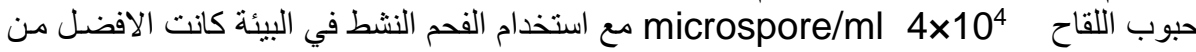

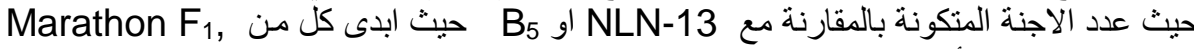
Parthenon F1 